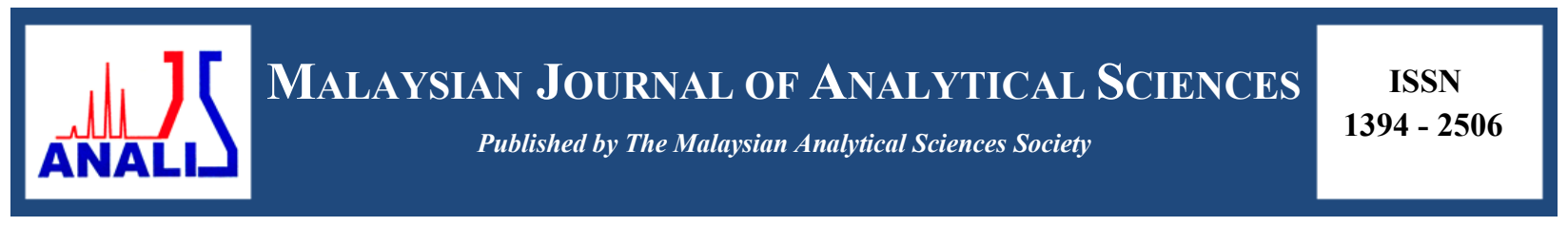

\title{
EFFECTS OF AGITATION CONDITIONS ON BACTERIAL CELLULOSE PRODUCTION BY Acetobacter xylinum 0416 IN FERMENTATION OF MATURED COCONUT WATER MEDIUM
}

\author{
(Kesan Goncangan ke atas Penghasilan Selulosa Bakteria oleh Acetobacter xylinum 0416 \\ Melalui Fermentasi Air Kelapa Tua)
}

\author{
Faezah Esa, Norliza Abd. Rahman*, Mohd Sahaid Kalil, Siti Masrinda Tasirin \\ Department of Chemical and Process Engineering, \\ Faculty of Engineering and Built Environment, \\ University of Malaysia, 43600 UKM Bangi, Selangor, Malaysia \\ *Corresponding author: norlizajkkp@ukm.edu.my
}

Received: 21 October 2015; Accepted: 14 June 2016

\begin{abstract}
Bacterial cellulose (BC), a pure form of three-dimensional biopolymer is gaining extensive interest due to its unique physical and mechanical properties. The effects of different agitation conditions on $\mathrm{BC}$ synthesis by Acetobacter xylinum 0416 have been compared. Fermentations were carried out at 150 and $200 \mathrm{rpm}$ using rotatory incubator shaker and rotatory shaker in a constant temperature room of $30^{\circ} \mathrm{C}$. Matured coconut water was used as a sustainable medium due to its low cost and availability. The medium was adjusted to $\mathrm{pH} 4.5$ or $\mathrm{pH} 5.5$ and $\mathrm{BC}$ pellets were collected after 7 days of fermentation. The constant temperature room appeared to has fluctuate degree of heat during fermentation up to $37^{\circ} \mathrm{C}$ and suppressed the $\mathrm{BC}$ production. In rotatory incubator shaker, the $\mathrm{BC}$ produced have insignificant different in comparison to $\mathrm{pH}$ and rotation speed. These results indicate that matured coconut water has potential as the carbon source for $\mathrm{BC}$ synthesis and optimization of fermentation temperature is important to produce enormous yield of BC.
\end{abstract}

Keywords: bacterial cellulose, matured coconut water, fermentation, agitation speed

\begin{abstract}
Abstrak
Selulosa bakteria (SB) iaitu sejenis tiga-dimensi biopolimer sedang mendapat tumpuan yang meluas disebabkan oleh sifat fizikal dan mekanikalnya yang unik. Kesan goncangan yang berbeza terhadap sintesis SB oleh bakteria Acetobacter xylinum 0416 telah dibandingkan. Proses fermentasi telah dilakukan pada kelajuan $150 \mathrm{rpm}$ dan $200 \mathrm{rpm}$ menggunakan inkubator penggoncang berputar yang tertutup dan inkubator penggoncang berputar terbuka yang terletak di dalam bilik malar pada suhu tetap $30{ }^{\circ} \mathrm{C}$. Air kelapa tua digunakan sebagai medium mapan kerana mudah diperoleh pada kos yang rendah. Media ini dilaraskan pada $\mathrm{pH} 4.5$ atau pH 5.5 dan pelet BS dikumpulkan selepas 7 hari fermentasi. Suhu bilik malar didapati berubah-ubah sepanjang fermentasi sehingga meningkat kepada $37^{\circ} \mathrm{C}$ dan membantutkan penghasilan SB. Melalui penggunaan inkubator penggoncang berputar yang tertutup, SB yang terhasil mempunyai perbezaan kuantiti yang tidak signifikan dari segi $\mathrm{pH}$ dan kelajuan goncangan. Keputusan ini menunjukkan air kelapa tua mempunyai potensi sebagai sumber karbon bagi sintesis SB dan pengoptimuman suhu fermentasi adalah penting untuk menghasilkan SB yang banyak.
\end{abstract}

Kata kunci: bakteria selulosa, air kelapa tua, fermentasi, kelajuan goncangan. 


\section{Introduction}

Cellulose is the most abundant biological polymer on earth, mainly synthesized on the plasma membrane of plants and assemble within the cell wall. It plays an important role in sustaining the integrity of this structure. Cellulose exhibited high stiffness, strength and high thermal stability. Concerning on its properties and enormous quantity available in nature, plant cellulose has been used in numerous purposes by man. However, plant cellulose has many impurities such as hemicellulose and lignin which require harsh treatment for removal [1]. Indeed, this development regrettably had created great problems to biosphere ecology particularly deforestation issue.

To overcome these problems, the use of bacterial cellulose (BC) has been suggested as a better choice in replacing plant cellulose. BC is synthesized extracellular by some bacteria especially by acetic acid bacteria [2]. Even though, $\mathrm{BC}$ has similar chemical formula with plant cellulose, its fibrils formation is chemically pure and possess superior physiochemical properties that plant cellulose cannot provide. This cellulosic microfibrils become a promising biomaterial in various fields including biomedical [3], food [4,5,6] and electronic [7,8]. Most Acetobacter xylinum strains produce high level of cellulose under static condition. However, development of large scale BC production by improving its fermentation system is important for cellulose production.

Coconut palm is the fourth important industrial crop planted in Malaysia after palm oil, rubber and paddy [9]. Food and Agriculture Organization of The United Nations Statistics Division [10] has state Malaysia had produced an average of 646932 tonnes of coconuts in 2013. Some coconut products traded in the world markets are coconut oil, copra, desiccated coconut and coir. In the meantime, matured coconut water become a common waste product from this process. The matured coconut water which is available in plenty amount and contains various essential contents [11] that support the growth of bacteria is suitable as an economical culture medium.

Thus, the objective of this study is to investigate the best conditions for cellulose growth from Acetobacter xylinum 0416 in an economic cost using matured coconut water as culture medium. The effect of three factors that are $\mathrm{pH}$ of the growth medium, rotation speed and incubation condition on the amount of cellulose produced were determined.

\section{Bacterial strain}

\section{Materials and Methods}

Acetobacter xylinum 0416 used in this study was supplied by The Malaysian Agricultural Research and Development Institute. The strain was sub-cultured in matured coconut water medium contains the following constituents per liter: D-glucose $80 \mathrm{~g}$, ammonium sulphate $5 \mathrm{~g}, 10 \%$ of inoculum and acetic acid glacial. All media were autoclaved at $120^{\circ} \mathrm{C}$ for 15 minutes. The working culture were prepared at $30^{\circ} \mathrm{C}$ for 3 days before used.

\section{Fermentation medium}

For fermentation, medium, matured coconut water residues were collected from copra dealer and been adjusted with glacial acetic acid to 4.5 or 5.5 . The culture medium was sterilized by autoclave at $120^{\circ} \mathrm{C}$ for $15 \mathrm{~min}$.

\section{BC synthesis}

Bacteria were fermented in matured coconut water culture medium of different $\mathrm{pH}$ and different rotation speed, 150 $\mathrm{rpm}$ and $200 \mathrm{rpm}$ for $\mathrm{BC}$ production (Table 1). Two types of fermentation condition were compared: 1 . Fermented in rotatory incubator shaker; 2. Fermented by rotatory shaker that has been placed in a constant temperature room of $30{ }^{\circ} \mathrm{C}$ (Controlled room) (Figure 1). The fermentation process was carried out at $30{ }^{\circ} \mathrm{C}$ for 7 days using experimental design shown in Table 1. 


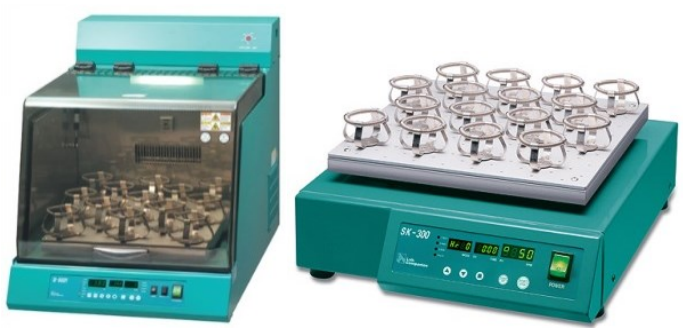

Figure 1. a) Rotatory incubator shaker; b) Rotatory shaker

Table 1. Experimental design of process variables.

\begin{tabular}{llll}
\hline No. & $\begin{array}{l}\text { Incubation } \\
\text { Types }\end{array}$ & $\begin{array}{l}\text { Rotation } \\
\text { Speed (rpm) }\end{array}$ & Initial pH \\
\hline 1 & & \multirow{2}{*}{150} & 4.5 \\
2 & & 5.5 \\
3 & Incubator & \multirow{2}{*}{200} & 4.5 \\
4 & & \multirow{2}{*}{150} & 5.5 \\
\hline 5 & & 4.5 \\
6 & & 5.5 \\
7 & Controlled room & 4.5 \\
8 & & 200 & 5.5 \\
\hline
\end{tabular}

At the end of fermentation, $\mathrm{pH}$ changes were measured using $\mathrm{pH}$ meter. The $\mathrm{BC}$ samples, harvested in both culture medium, were rinsed with water and subsequently treated with $0.1 \mathrm{M} \mathrm{NaOH}$ solution for 20 minutes at $100{ }^{\circ} \mathrm{C}$ and thoroughly washed with water until total neutralization.

\section{Dry weight of BC}

To determine the dry weight of $\mathrm{BC}$, the purified samples were dried at $45{ }^{\circ} \mathrm{C}$ until reaching constant weight and kept for further characterization.

\section{Results and Discussion}

In coconut water medium, acetic acid was used to bring down the $\mathrm{pH}$ as it had a better effect on Acetobacter xylinum 0416 growth compared to other acids [12]. The acetic acid was broken down to carbon dioxide and water which allow more energy generated by bacteria. Thus, leading to more efficient utilization of sugars for cellulose synthesis [13].

After 7 days of fermentation, the final $\mathrm{pH}$ of each samples was measured. Most the highest yield for Acetobacter xylinum 0416 strains were achieved after seven days of incubation [14,15]. Figure 2 represents reductions of $\mathrm{pH}$ from their initial values. Both $\mathrm{pH}$ of culture in fermented in rotatory incubator shaker decreased to less than $\mathrm{pH} 3.7$ while fermentation in controlled room have $\mathrm{pH}$ reduction in a range of 4.08 to 4.38 . This analysis suggests that culture in incubator have better carbon consumption for growth than culture in controlled room. 


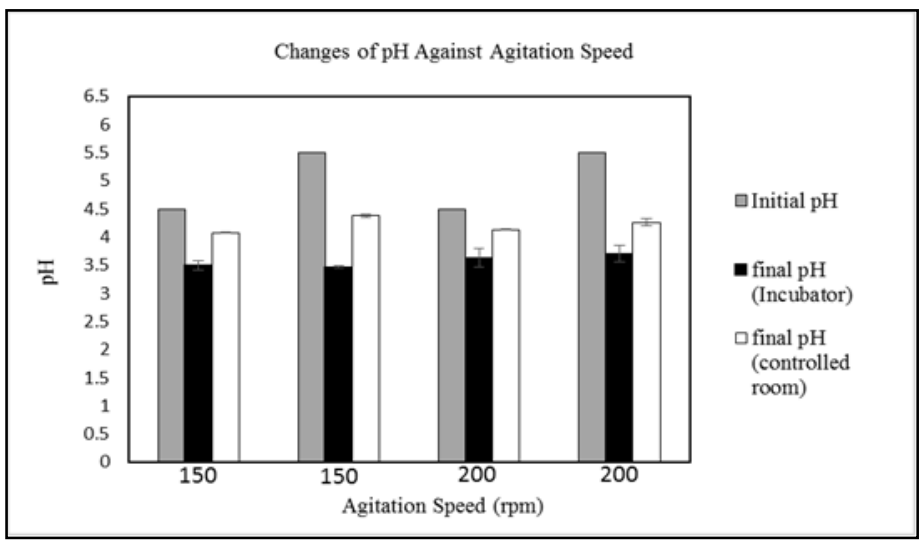

Figure 2. $\mathrm{pH}$ changes on various agitation speed and incubation types

Comparison on $\mathrm{BC}$ structure (Figure 3) and yield of both fermentation conditions were made. BC commonly produced in the form of gelatinous pellicle through static condition. However, some strains of cellulose-producing bacteria could produce sphere-like cellulose under agitated process while other strains were unable to exhibit this capability even under the same condition. The formation of this sphere-like shape might result from the shear force produced during agitation cultivation that cause intertwine of cellulose ribbon. In this study, Acetobacter xylinum 0416 was unable to produce sphere-like cellulose. The cellulose had irregular shape which appear in chunk and aggregate form. This finding suggesting that the structure of cellulose is not universally produce by Acetobacter xylinum 0416 strains [16].
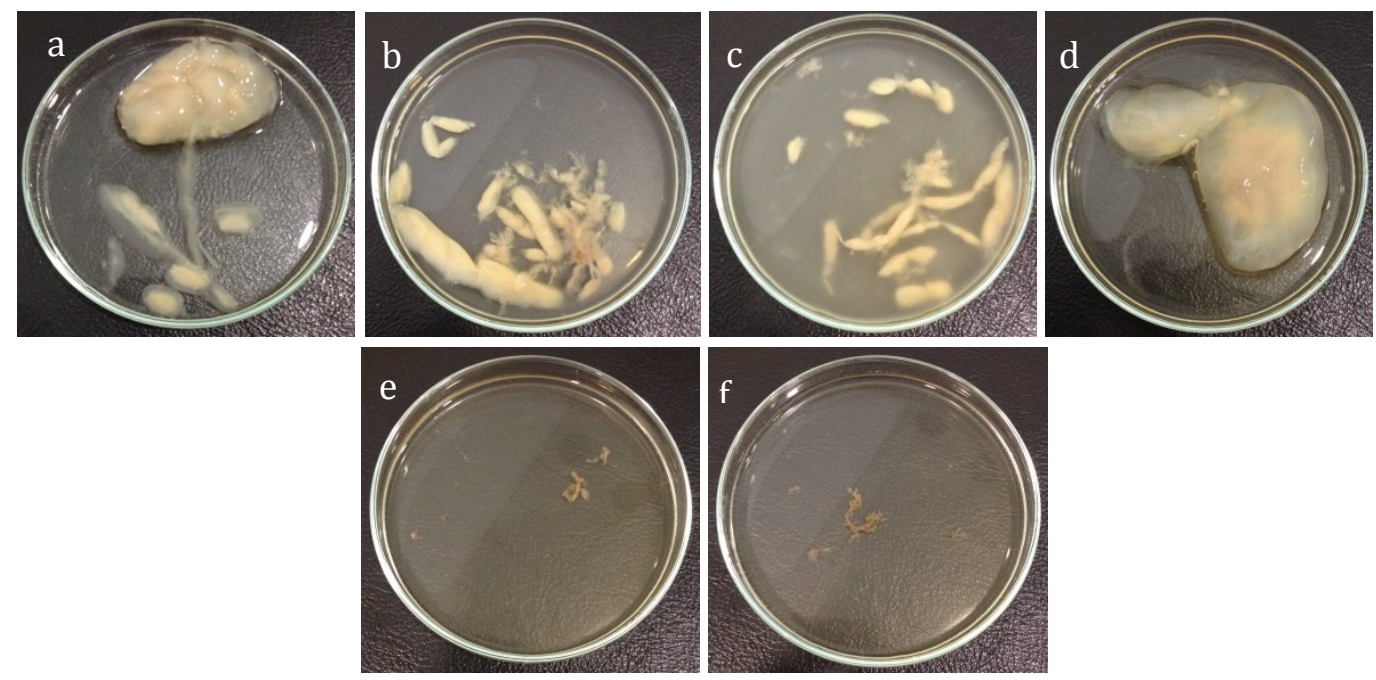

Figure 3. Fermentation of culture medium at rotation speed of (a-b) $150 \mathrm{rpm}$ in incubator shaker, (c-d) $200 \mathrm{rpm}$ in incubator shaker and (e-f) 150 and $200 \mathrm{rpm}$ in controlled room

There was no $\mathrm{BC}$ formation at $\mathrm{pH} 4.5$ and $\mathrm{pH} 5.5$ after 7 days fermentation in controlled room. The culture was unable to produce any $\mathrm{BC}$ even though the growth of bacteria did occur (reduction of $\mathrm{pH}$ ). This might result from unstable temperature of controlled room during this fermentation process where the temperature kept fluctuate up to $37^{\circ} \mathrm{C}$. 
Some factors can cause temperature fluctuation was often opening of controlled room as it was free access to anyone. When the door was open, more heat and humidity to be released and it will take longer time to reach its normal temperature. Besides that, when the machines in the room were turned on, the internal heat sources released cause disturbance to the constant temperature. Hence, the heat must be compensated with a proper cooling system.

Table 2 summarized the dry weight of cellulose produced by Acetobacter xylinum 0416 under different rotational speeds, initial $\mathrm{pH}$, and incubation condition. Based on this data, an increase in the biomass yield in increasing cultivation rotational speed might due to improved aeration. Moreover, these results proposed that there was no relationship between cellulose yield and $\mathrm{BC}$ sizes for this strain.

Table 2. Bacterial production on various types of incubation, agitation speed and $\mathrm{pH}$

\begin{tabular}{|c|c|c|c|c|}
\hline No. & Incubation Types & $\begin{array}{l}\text { Rotational speed } \\
\text { (rpm) }\end{array}$ & Initial pH & $\begin{array}{c}\text { Dry Weight } \\
\text { (g) }\end{array}$ \\
\hline 1. & \multirow{4}{*}{ Incubator } & \multirow{2}{*}{150} & 4.5 & 0.047 \\
\hline 2. & & & 5.5 & 0.035 \\
\hline 3. & & \multirow{2}{*}{200} & 4.5 & 0.098 \\
\hline 4. & & & 5.5 & 0.137 \\
\hline 5. & \multirow{4}{*}{ Controlled room } & \multirow{2}{*}{150} & 4.5 & 0 \\
\hline 6. & & & 5.5 & 0 \\
\hline 7. & & \multirow{2}{*}{200} & 4.5 & 0 \\
\hline 8. & & & 5.5 & 0 \\
\hline
\end{tabular}

\section{Conclusion}

Matured coconut water has potential as an economic medium which can serve as carbon substrates for BC production. Choosing the right incubation process is important to maximize the yield of $\mathrm{BC}$ synthesis. Besides that, more study should be done on different rotational speed to have high yield in short duration of fermentation.

\section{References}

1. Ummartyotin, S. and Manuspiya H. (2015). A critical review on cellulose: From fundamental to an approach on sensor technology, Renewable and Sustainable Energy Reviews, 41: 402 - 412.

2. Sengun, I. Y. and Karabiyikli, S. (2011). Importance of acetic acid bacteria in food industry. Food Control, 5: $647-656$.

3. Wu, J., Zheng, Y., Song, W., Luan, J., Wen, X., Wu, Z., Chen, X., Wang, Q. and Guo. S. (2014). In situ synthesis of silver-nanoparticles/bacterial cellulose composites for slow-released antimicrobial wound dressing. Carbohydrate Polymer, 102: $762-771$.

4. Pérez, C. D., De’Nobili, M. D., Rizzo, S. A., Gerschenson, L. N., Descalzo, A. M. and Rojas, A. M. (2013). High methoxyl pectin-methyl cellulose films with antioxidant activity at a functional food interface. Journal of Food Engineering, 116: $162-169$.

5. Lin, S. B., Chen, L. C. and Chen, H. H. (2011). Physical characteristics of surimi and bacterial cellulose composite gel. Journal of Food Process Engineering, 34: 1363 - 1379.

6. Shi, Z., Zhang, Y., Phillips, G. O. and Yang, G. (2014). Utilization of bacterial cellulose in food. Food Hydrocolloids, 35: 539 - 545.

7. Zhou, T., Chen, D., Jiu, J., Nge, T. T., Sugahara, T., Nagao, S., Koga, H. and Nogi. M. (2013). Electrically conductive bacterial cellulose composite membranes produced by the incorporation of graphite nanoplatelets in pristine bacterial cellulose membranes. Polymer Letters, 7(9): 756 - 766. 
8. Gadim, T. D. O., Figueiredo, A. G. P. R., Rosero-Navarro, N. C., Vilela, C., Gamelas, J. A. F., BarrosTimmons, A., Neto, C. P., Silvestre, A. J. D., Freire, C. S. R. and Figueiredo, F. M. L. (2014). Nanostructured bacterial cellulose-poly(4-styrene sulfonic acid) composite membranes with high storage modulus and protonic conductivity. ACS Applied Material Interfaces, 6(10): 7864 - 7875.

9. Sivapragasam A. (2008). Coconut in Malaysia - Current development and potential for re-vitalization. $2^{\text {nd }}$ International Plantation Industry Conference and Exhibition (IPICEX2008).

10. Food and Agriculture Organization of The United Nations Statistics Division (2015). Access from http://faostat3.fao.org/compare/E [28 July 2015].

11. Prades, A., Dornier, M., Diop, N. and Pain, J. P. (2011). Coconut water uses, composition and properties: A review. Fruits, 67 (2):87 - 107.

12. Jagannath, A., Kalaiselvan, A., Manjunatha, S. S., Raju, P. S. and Bawa, A. S. (2008). The effect of pH, sucrose and ammonium sulphate concentrations on the production of bacterial cellulose (Nata-de-coco) by Acetobacter xylinum. World Journal of Microbiology and Biotechnology, 24: 2593 - 2599.

13. Vandamme E. J., de Baets, S., Vanbaelen, A., Joris, K. and de Wulf, P. (1998). Improved production of bacterial cellulose and its application potential. Polymer Degradation and Stability, 59: 93 - 99.

14. Cavka, A., Guo, X., Tang, S. Winestrand, S., Jonsson, L. J. and Hong, F. (2013). Production of bacterial cellulose and enzyme from waste fiber sludge. Biotechnology for Biofuels. 6: $25-35$.

15. Huang, C., Yang, X. Y., Xiong, L., Guo, H. J., Luo, J., Wang, B., Zhang, H. R., Lin, X. Q. and Chen, X. D. (2013). Evaluating the possibility of using acetone-butanol-ethanol (ABE) fermentation wastewater for bacterial cellulose production by Gluconacetobacter xylinus. Letters in Applied Microbiology, 60(5): 491 - 496.

16. $\mathrm{Hu}, \mathrm{Y}$. and Catchmark, J. M. (2010). Formation and characterization of spherelike bacterial cellulose particles produced by Acetobacter xylinum JCM 9730 strain. Biomacromolecules, 11:1727 - 1734. 